\title{
Effects of Amylase and Inverlase Regulators Upon Sugar Content, Protein Content, and Enzyme Activity of Immature Sugarcane
}

\author{
Alex G. Alexander
}

\section{INTRODUCTION}

Although invertase and anylase rank anong the most ancient of enzymes known to biologists $(7 j, 18),{ }^{2}$ little efiort has been made to regulate these catulysts in living plants. With regard to sugarenne, it has become increasingly evident that their control might offer a means of promoting sugar formation. Stulies in Puerto IRico have related bolh anylase $(1,2)$ and invertase $(3,7)$ to sucrose content. Hart correlited activity with the areas of active sugar formation $(10)$, and with polassium supply $(11,12)$. Investigations by Hateh and coworkes's $(13,1 / 4)$ and by Crlasziou $(9)$ have rlarified roles of invertase in sugar movement and accumulation.

Recent in vilio studies have shown that the invertase and amylase systems of ewe are both plentiful and lugged $(4, j)$. However, these cnzymes were readily inhibited by mereury and iodide, and they were stimulated by manganese." It was thus comsidered possible thit the same materials might ('ause enzyme suppression or stimulation if supplied to living canc. To test this hypothexis, craluations were made of invertake and amylase from cane which had received $\ \mathrm{In}$ and $\mathrm{Hg}$ as foliar sprays and nutrientsolution supplenents.

\section{NIATEKIALS AND METHOHS}

P'lants of the varity M.3336 were glown by sand culture in the greenhouse, aceording to procedures established earlier (6). Two cxperiments were condurled; one, involving loliar applications of $\mathrm{An}$ and $\mathrm{Hg}$, and a "cond with supplemental additions of MIn and $\mathrm{Hg}$ to the standard nutrient solutions."

Twelve-wock-old plants were employed for experiment 1. Mangancses

'Assoriate l'lant Milysiolngist, Agrieultural Experiment Station, Universily of P'uerto Rico, Rio Piedris, P.R.

2 Italic numbers in parentheses reler to Literature Cited pp. 34-5,

"Abbreviations: Mercury, ( $\mathrm{Hg}$ ); iodide, (I); mangnnouc, (Mn); glucose-1-phosphate, (G-L-I); adenosine trijhlosphate, (ATP); $\beta$-glycerophosphnte, ( $\beta$-GP); and parts per million, (p.p.m.).

4 All plants recejved the following macronutionts, expressed us milliequivalents per liter: Nitrate, 10; phosphate, 6; potassium, 5; calcium, 3; magnesium, 2; und sulfute, 2. Microelenents, expressed as parts per million. were supplied as follows: Boron, 0.05; copper, 0.02; manganese, 0.50; zinc, 0.05; molybdenum, 0.01; and iron, 0.50 . 
and $\mathrm{Hg}$ were applied in distilled water at rales of 50 and 1,000 p.p.m., using "tween 20" as wetting agent at the rate of $0.10 \mathrm{ml}$. per $100 \mathrm{mI}$. of solution. Conlrol plants received distilled water plus wetting agent. Each solution was applied with a hand sprayer until all above-sand portions of the plants were thoroughly wet and run-off had begun.

Nutrient solutions for the second experiment were provided on Tuesdays, Thursdays, and Saturdays, beginuing with 10-week-old plants and continuing over « period of 5 weeks. Distilled water was given on altemate days. Manganese levels were 2.5 and 25.0 p.p.m., whereas $\mathrm{Hg}$ variables were established at 0.05 and 1.0 p.p.m. Arscnate, $W$, and I were also tested as nutrient-solution supplements, ench at concentrations of 0.05 and 1.0 p.p.m. All treatments were replicated 3 limes, and the experimental design was a completely randomized block for each study.

Leaf and meristen tissues were harvested during both experiments for sugar and enzyme analyses. Sumpling technique and subsequent freezedrying procedures have been described previously $(6)$. Samples were taken from experiment 1 a few moments prior to foliar treatments, and again 3 , 9 , and 27 days therealtor. Experiment 2 was harvested once after the plants had been treated for 5 weeks.

Sugars and enzyme protein were extracted from powdered, freeze-dried tissues as described in an earlier report (1). Total ketoses were determined with clarified extracts by the resoreinol method of Roe (16), and sucrose by the modification of Caudini et al. (8). Fructose was estimated by subtracting sucrose: values from those of lotal kelose. Protein was precipitated with ammonium sulfate from clarified extracts, ats pF 7.0 and $22^{\circ} \mathrm{C}$, and taken up in distilled water. The rechuicute of Sutherland et al. (1\%) was used to measure protein content.

Fnzymes assayed during the prescut investigntions included anylase, invertase, and the acid phosphatases which hydrolyze $\beta$-CP, ATP, and G-1-P. Phosphatase procedures were described previously (I), as were those for anylase (j) and invertase (/4).

All data gathered during these studies were subjected to statistical analysis of variance, and menns were compured by the Student-Newman-Keuls Q test (table 1).

\section{RESULTS AND DISCUSSION}

EXPERLMENT 1: FOLIAR APPLICATION OF MANGANESE AND MERCURY

\section{Leaf and meristem sugars}

Whereas manganese had no effect on leaf and meristem sugar levels, high $\mathrm{Hg}$ caused a pronounced deterioration of leal-sucrose content (table 2 , item 10). This was still evident 27 days after treatment (fig. 1). The 
TABLE 1.-Summary of significant mean differences among sugar, enzyme, and protein values for sugarcane treated with regulators of invertase and amylase ${ }^{1}$

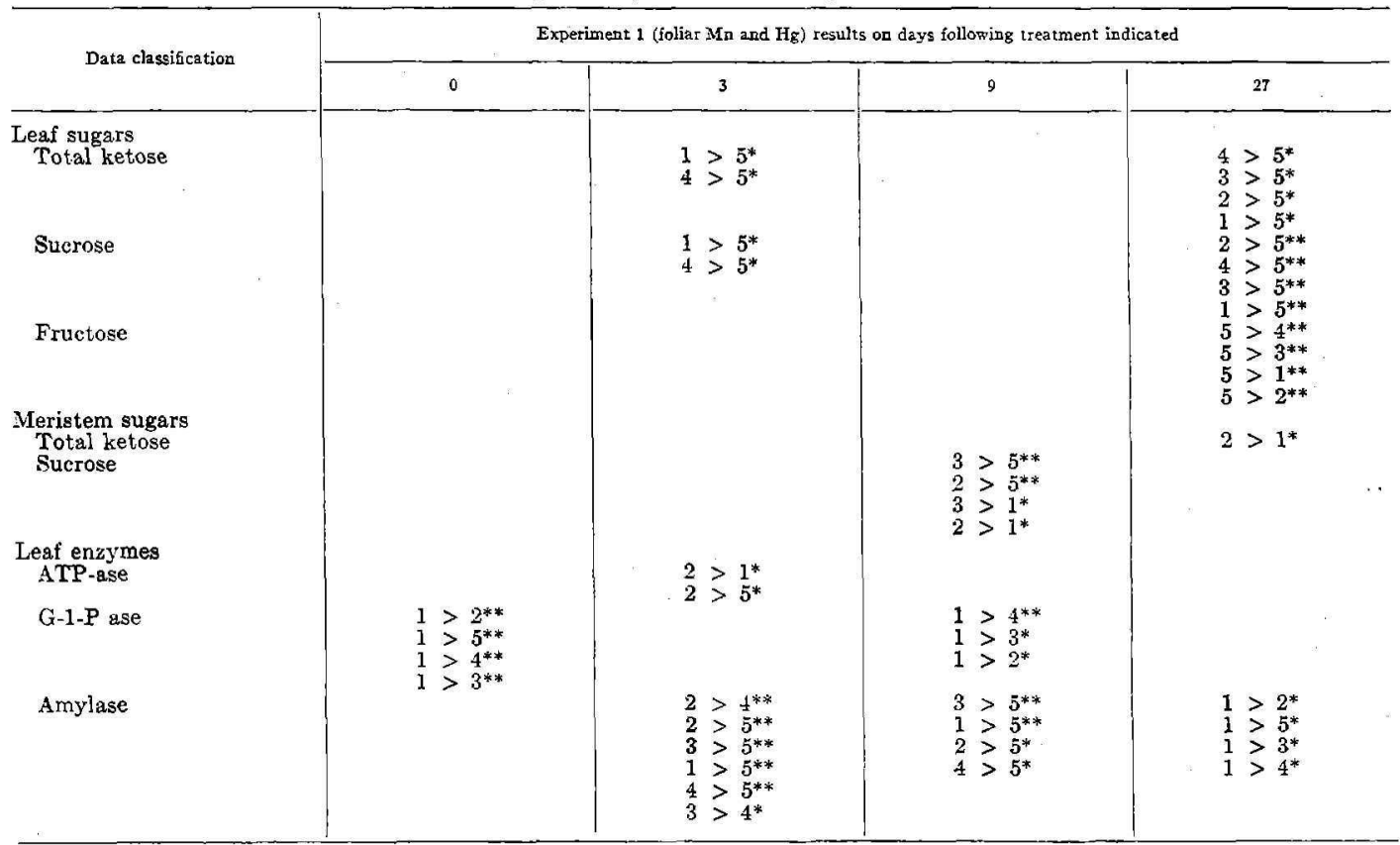




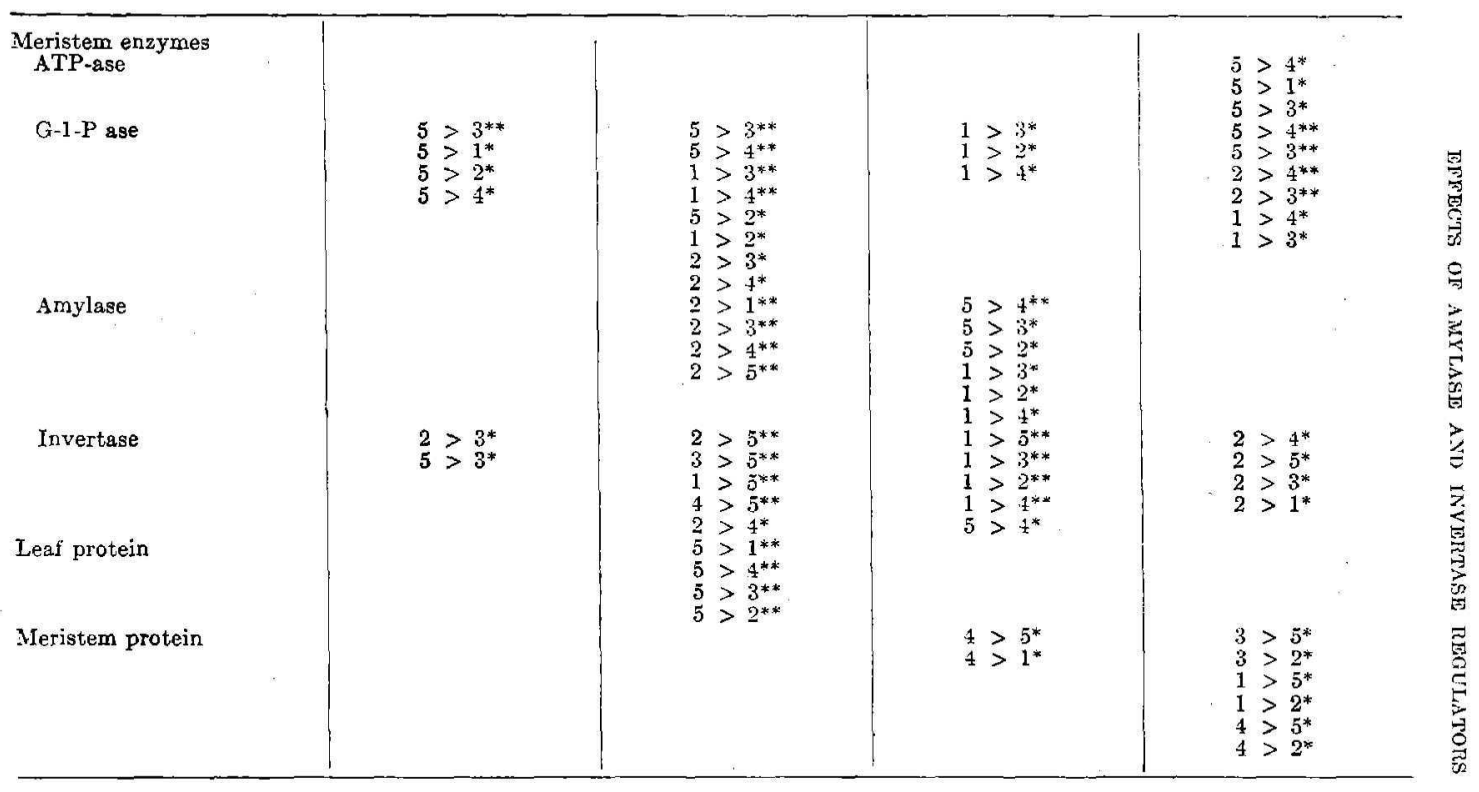


T'ABLE 1.-Continued

\begin{tabular}{|c|c|c|c|c|c|c|c|c|c|c|c|c|}
\hline \multirow{2}{*}{ Tissue } & \multicolumn{12}{|c|}{ Experiment 2 (nutritent-solution supplements) significant mean difierences are summarized for the indicated criteria- } \\
\hline & Tulial ketose & Sucrose & Fructose & ATP-zse & G-1-P ase & & Amylase & & Invertase & & Protei & \\
\hline Leaf & & & & $\begin{aligned} 8 & >7^{*} \\
6 & >7^{*} \\
4 & >7^{*} \\
11 & >7^{*}\end{aligned}$ & $\begin{array}{l}1>4^{* *} \\
1>0^{* *} \\
1>7^{* *} \\
1>3^{* *} \\
1>11^{* *} \\
1>5^{* *} \\
1>9^{* *} \\
1>10^{* * *} \\
2>5^{* *}, \text { etc. } \\
5>10^{*} \\
5>9^{*} \\
4>10^{*} \\
6>10^{*} \\
7>10^{*}\end{array}$ & $\begin{array}{r}11 \\
0 \\
8 \\
4 \\
2 \\
7 \\
1 \\
10 \\
3 \\
6 \\
5\end{array}$ & $\begin{array}{l}>5^{* *} \\
>5^{* *} \\
>5^{* *} \\
>5^{* *} \\
>5^{* *} \\
>5^{* *} \\
>5^{*} \\
>5^{*} \\
>5^{*} \\
>5^{*} \\
>5^{*}\end{array}$ & & $\cdot$ & $\begin{array}{l}6 \\
5 \\
6 \\
5 \\
4\end{array}$ & $\begin{array}{l}> \\
>8 \\
>1 \\
>1 \\
>\end{array}$ & $\begin{array}{l}8^{* *} \\
8^{* *} \\
11^{*} \\
11^{*} \\
8^{*}\end{array}$ \\
\hline Meristem & $\begin{array}{l}7>8^{* *} \\
2>8^{* *} \\
7>9^{*} \\
2>9^{*} \\
1>9^{*}\end{array}$ & $\begin{array}{l}2>8^{* *} \\
7>8^{* *} \\
2>9^{*} \\
2>11^{*} \\
2>10^{*} \\
7>9^{*} \\
7>11^{*} \\
7>10^{*} \\
1>10^{*} \\
1>8^{*}\end{array}$ & $6: 9^{*}$ & $1>5^{*}$ & $\begin{aligned} 7 & >8^{* *} \\
i & >2^{* *} \\
i & >1^{* *} \\
7 & >3^{* *} \\
7 & >t^{* *} \\
7 & >5^{* *} \\
7 & >6^{* *} \\
11 & >3^{* *} \text {, etc. } \\
9 & >3^{* *}, \text { etc. } \\
10 & >3^{* *}, \text { etc. } \\
8 & >5^{* *} \\
8 & >6^{* *} \\
2 & >5^{* *} \\
2 & >6^{* *} \\
1 & >6^{* *} \\
7 & >11^{*}, \text { etc. } \\
2 & >3^{*} \text {, ete. } \\
1 & >3^{*} \text {, etc. }\end{aligned}$ & $\begin{array}{l}73 \\
\frac{7}{7} 3 \\
\frac{1}{7} 3 \\
7 \\
7 \\
9 \\
1 \\
2 \\
9 \\
1 \\
2 \\
10\end{array}$ & $\begin{array}{l}>10^{* *} \\
>11^{* *} \\
>5^{* *} \\
>6^{* *} \\
>3^{* *} \\
>4^{* *} \\
>5^{* *} \\
>0^{* *} \text {, etc. } \\
>9^{* *} \text {, etc. } \\
>5^{* *} \text {, etc. } \\
>5^{*} \text {, etc. } \\
>8^{*} \text {, etc. } \\
>6^{*} \text {, etc. } \\
>5^{*}\end{array}$ & $\begin{array}{r}10 \\
10 \\
10 \\
10 \\
10 \\
10 \\
10 \\
8 \\
9 \\
11 \\
11 \\
9 \\
11\end{array}$ & $\begin{array}{l}>7^{* *} \\
>3^{* * *} \\
>4^{* *} \\
>2^{* *} \\
>6^{* *} \\
>5^{* *} \\
>1^{* *} \\
>2^{* *} \text {, etc. } \\
>6^{* *} \text {, etc. } \\
>5^{* *} \\
>1^{* *} \\
>3^{*}, \text { etc. } \\
>4^{*} \text {, etc. }\end{array}$ & $\begin{array}{r}5 \\
6 \\
3 \\
8 \\
1 \\
11\end{array}$ & $\begin{array}{l}> \\
> \\
> \\
> \\
> \\
>\end{array}$ & $\begin{array}{l}7^{* *} \\
7^{*} \\
i^{*} \\
i^{*} \\
i^{* *}\end{array}$ \\
\hline
\end{tabular}

${ }^{1}$ The numbers and symbols used to prepare this table are defined as follows: For experiment 1 , numbers 1 through 5 represent mean values for control, Mr, and $\mathrm{H}$ greatments. Experiment $1, \mathrm{No} .1=\mathrm{Control} ; 2=\mathrm{Mn}, 50 \mathrm{p} . \mathrm{p} . \mathrm{m}$.; $3=\mathrm{Mn}, 1,000 \mathrm{p} . \mathrm{p} . \mathrm{m}$; $1=\mathrm{Hg}$,

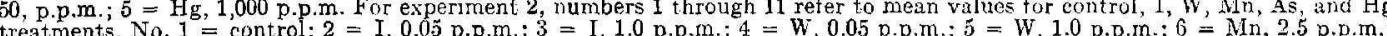
$7=\mathrm{Mn}, 25.0$ p.p.m.; $\delta=$ As, 0.05 p.p.m.; $9=$ As, 1.0 p.p.m.; $10=\mathrm{Hg}, 0.05$ p.p.m.; $11=$ Hg. 1.0 p.p.m. The symbol $>$ appearing between 2 figures indicates that the frst mean was of greater magnitude than the second. significant mean difference at the jpercent level is denoted by 1 asterisk, and at the 1 -percent level by 2 asterisks. 
loss of sucrose was not at once accompanied by increased lructose, as one night have expected if a simple inversion were involved. Curiously, a marked rise in fructose did appear at 27 days (table 2 , item 15), at the same period when control plants experienced their only fructose decline (table 2, item 11). Mercury thus transmuted the control response for fructose, while maintaining a continued suppression of sucrose.

Meristem sugar data (table 3) exemplify the difficulty of diverting inmature cane from a physiologieal course it has set itself upon. 'The only

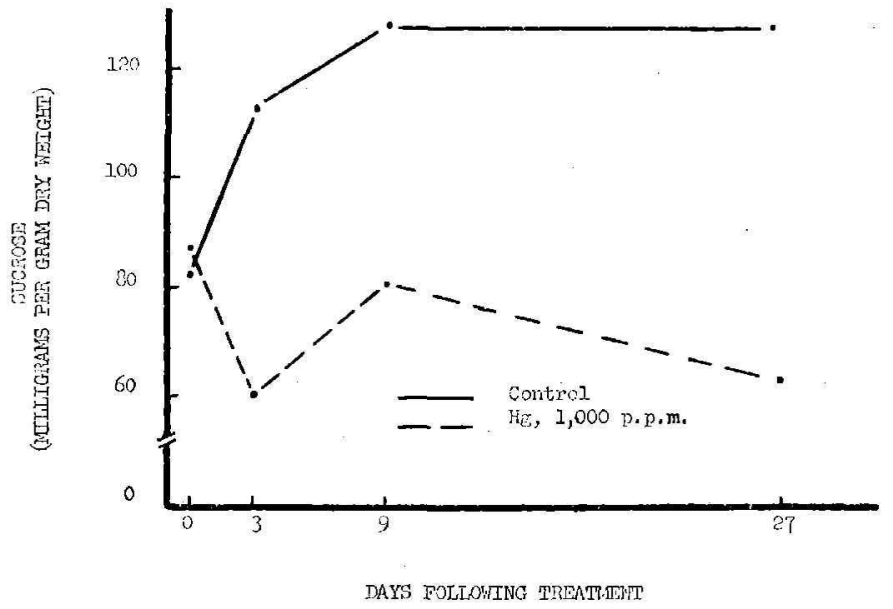

Fra. 1.-Decline of leaf-sucrose content of immalure sugateme following foliar appliention of mercury.

consistent trends anong meristem sugas were an abrupt increase in sucrose at 27 days, coupled with a fructose decline during the stume period (table 3, itens 6 to 10 us. ifems 12 to 15). High $\mathrm{MIn}$ lessened the sucrose: changes and $\mathrm{Hg}$ increased them (fig. 2). But the overall trend, as established by control plants, remained essentially the same. This was particularly surprising with resped. (o) the plants receiving high $\mathrm{Hg}$, for their foliage at once appened so scorehed and desiceated that it was doubtul whether they would live for tho duration of the study. Meristem-sugar dala give no inkling that any severo shock had occurred. This again suggests that the plants had heen able to confine $\mathrm{Hg}$ effects to their leaves. 


\section{Leaf and meristem enzymes}

Neither ATP-ase nor G-1-P ase was consistently affected by the Mn and Hg treatments in leaf and meristem. Amylase was markedly suppressed by both levels of $\mathrm{Hg}$ in leaves (table 4, items 14 and 15 ; figure 3 ). As was true of sucrose decline in leaves, the leaf-amylase response was not repeated in meristem. However, some influence was being exerted upon meristem

TAв r.: 2.-Leaf sugar content of immature sugarcane following foliar application of manganese and mereury ${ }^{\mathrm{L}}$

\begin{tabular}{|c|c|c|c|c|c|c|c|}
\hline \multirow{2}{*}{ Item No. } & \multirow{2}{*}{ Sugar } & \multirow{2}{*}{ Treatment:2 } & \multicolumn{4}{|c|}{$\begin{array}{c}\text { Results on days following treatment } \\
\text { indicated }\end{array}$} & \multirow{2}{*}{ Mean } \\
\hline & & & $\mathbf{0}$ & 3 & 9 & 27 & \\
\hline 1 & Total ketose & Control & 127.4 & 151.5 & 169.9 & 150.3 & 149.8 \\
\hline 2 & & Mn 50 & 117.9 & 127.1 & 168.6 & 154.0 & 141.9 \\
\hline 3 & & $M n 1,000$ & 121.9 & 120.3 & 176.3 & 159.0 & 144.4 \\
\hline 4 & & $\mathrm{Hg} 50$ & 126.8 & 137.7 & 171.7 & 165.8 & 150.5 \\
\hline 5 & & $\mathrm{H}$ is 1,000 & 131.8 & 104.1 & 122.6 & 129.2 & 121.0 \\
\hline 6 & Sucrose & Control & 82.7 & 113.3 & 127.9 & 127.5 & 112.9 \\
\hline 7 & & $\mathrm{Mn} 50$ & 75.8 & 90.2 & 133.1 & 132.8 & 108.1 \\
\hline 8 . & & Mu 1,000 & $81 . \overline{5}$ & 87.3 & 107,1 & 130.0 & 101.5 \\
\hline 9 & & $\mathrm{H}_{\mathbf{g}} 50$ & 78.2 & 96.8 & 121.8 & 131.5 & 107.8 \\
\hline 10 & & $\mathrm{Hg} 1,000$ & 87.6 & 60.1 & 80.4 & 62.4 & 72.6 \\
\hline 11 & Fruetose & Control & 44.7 & 38.2 & 40.7 & 22.8 & 30.6 \\
\hline 12 & & $\mathrm{Mn} 50$ & 41.9 & 27.2 & 35.2 & 21.1 & 33.9 \\
\hline 13 & & Mn 1,000 & 40.5 & 33.0 & 35.9 & 29.0 & 31.6 \\
\hline 14 & & $\mathrm{Hg}_{\mathrm{g}} 50$. & 18.7 & 40.9 & 46.0 & 34.3 & 42.7 \\
\hline 15 & & $\mathrm{Hg} 1,000$ & 44.2 & 44.1 & 42.3 & 60.9 & 49.4 \\
\hline
\end{tabular}

' Wach figure represents the compuled monu of 3 replinales. Sugars aro expressed as milligrams per gram of tiry weight.

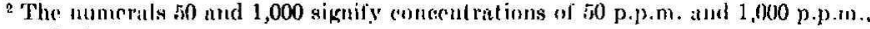
respectively:

amylase by $\mathrm{Hg}$, as evidenced by an accentuation of enzyme fluctuations with low $\mathrm{Hg}$, and by a moderating effect upon amylase from high $\mathrm{Hg}$ (table 5, ilems 14 and 15 ).

Meristem uvertase was nol inhibited by $\mathrm{Hg}$ nor stinulated by $\mathrm{Mn}$. linther, Hg and Mn sufficed ouly to revian trealed plants from experioncing invertase extremes such as that shown by conteol plants at 9 days (table 5). Such cqualifying effects upon anylase and invertase by enzyme regulators are a far cry finm the vivid inhibitory and stimulating effects observed in vitro. Notwithslanding, it would hardly be prudent to discount 
the theory that $\mathrm{Mn}$ and $\mathrm{Hg}$ an infuence enzymes in living tissues, nor to ponder what advantages such in vivo action might one day offer the wise investigator.

Taвit 3.-Meristem sugar content of immature sugarcane following foliar application of manqanese and mercu' $)^{\prime}$

\begin{tabular}{|c|c|c|c|c|c|c|c|}
\hline \multirow{2}{*}{ Item No. } & \multirow{2}{*}{ Sughir } & \multirow{2}{*}{ Trea $\mid$ nient $t^{2}$} & \multicolumn{4}{|c|}{$\begin{array}{l}\text { Results on diys following treatment } \\
\text { indicated }\end{array}$} & \multirow{2}{*}{$\mathbf{M} \tan$} \\
\hline & & & 0 & 3 & 9 & 27 & \\
\hline 1 & Total ketose & Comleol & 326.7 & 304.2 & 3.43 .9 & 269.9 & 311.2 \\
\hline 2 & & Mrt 50 & 271.4 & 316.8 & 316.8 & 329.8 & 333.7 \\
\hline 3 & & $M_{11} 1,000$ & 390.0 & 354.5 & 328.3 & 284.3 & 339.5 \\
\hline 4 & & $\mathrm{Hg} 50$ & 370.5 & 324.6 & 321.9 & 303.8 & 330.2 \\
\hline 5 & & $\mathrm{Hgt} 1,000$ & 384.4 & 336.7 & 281.8 & 308.9 & 327.9 \\
\hline 6 & Finerose: & $\sin (r)$ & 84.1 & 79). .3 & 83.2 & 123.0 & 01.1 \\
\hline 7 & & Mn 50 & 94.0 & 91.1 & 106.2 & 153.0 & 111.2 \\
\hline 8 & & Mn 1,000 & 91.9 & 104.9 & 107.2 & 124.3 & 107.3 \\
\hline 9 & & $\mathrm{Hg} 50$ & 87.5 & 72.8 & 88.8 & 130.5 & 97.2 \\
\hline 10 & & $\mathrm{H}_{\mathrm{s}} 1,000$ & 82.8 & 84.9 & 72.9 & 147.7 & 97.1 \\
\hline 11 & Fruetose & Control & 242.7 & 224.9 & 260.9 & 146.9 & 218.9 \\
\hline 12 & & $\mathrm{Mn} 50$ & 277.3 & 225.3 & 210.6 & 176.4 & 222.4 \\
\hline 13 & & $\mathrm{Mn} 1,000$ & 280.0 & 262.6 & 221.0 & 159.5 & 232.0 \\
\hline 14 & & $\mathrm{Hg} 50$ & 282.9 & 251.8 & 233.1 & 164.5 & 233.1 \\
\hline 15 & & Hg 1,000 & 301.6 & 251.8 & 208.9 & 161.2 & 233,4 \\
\hline
\end{tabular}

1 Euch figure represents the conuputed menn of 3 replicatus. sugars are expressed as milligrums per gram of dry weight.

2 The unmerals 50 and 1,000 signify concentrations of 50 p.p.ut. and 1,000 p.p.m., respectively.

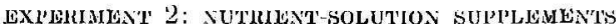

\section{Leaf and meristem sugars}

Meristem tissues rather than leaves revealed the greatest sugar changes when $\mathrm{Hg}$ and $\mathrm{M}$. were provided as nutrient supplements. Low Hg caused a slight sucrose decline in leaves (table 6, item 4), whereas meristem sucrose wus severely lowered by both $\mathrm{Hg}$ treatunents (table 6, itums 4 and 5). Iructose did not increase, so again inversion does not appenr to have been involved. Low Mn likewise indueed a sucrose declime in meristen (table 6,

- Technicully, no true in vivo enzyne mensurements were taken during this study. The term in vilro, as herein employed, refers to the effects of enzyme regulators upon calulysts in the test tube, and in vivo velers to the properties of enzymes extracted from plants which had been supplied with enzyme regulators while still alive. 
itcm 2), and this is move nearly accounted for by a concurent increase of fructose.

However, the most severe change in moristen sugur content was aused by low As, a treatment which lowered sucrose content to less than half of control values (table 6 , item 10 ). Arsente does not affeut cane invertase in vitro (13), and the failure of low As to increase fruetose again tends to discount invertase as the merhanism of sucrose decline.

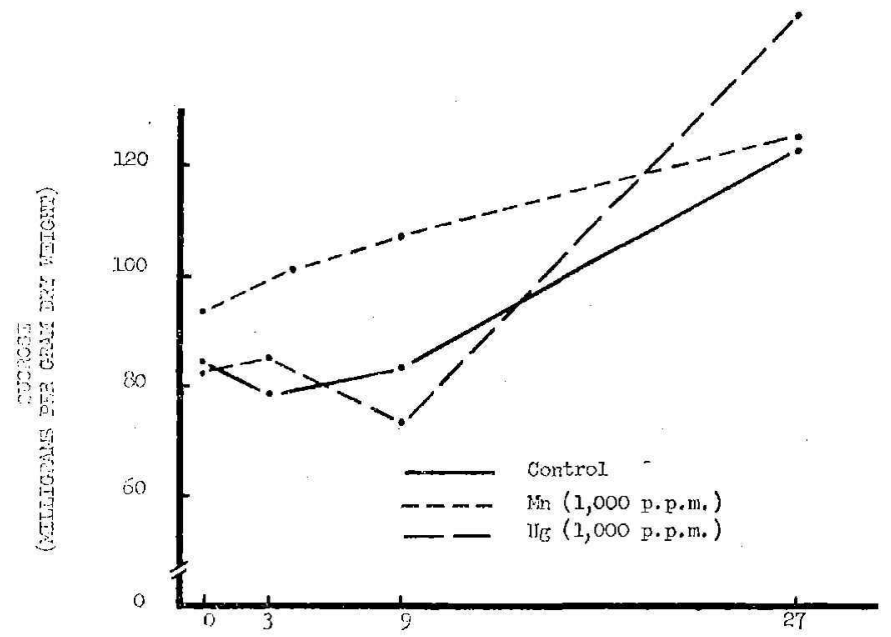

DAYS TOILOWING TREATHEMY

156. 2. Sucrose changes in meristem of immature sugarcane following foliar application of manganese.

The only treatment at all inclined toward increasing meristem sucrose was the low $\mathrm{W}$ supplement (table 6 , item 8 ). This increase was apparently mediated at the expense of fructose content. Conversely, the very slight sucrose increases caused by low I and high MIn (table 6, items 6 and 3) were the resulit, of a generul increase of total ketose.

\section{I,eaf and meristem enzymos}

Manganese and mercury supplied through the roots failed to influence amylase and invertase in a manner anticipated from in vitro studies. Mercury, the amylase-invertase inhibitor, greatly stimulated neristem invertase (Lable 7 , item 5 ), whereas neither of the Mu treatments apprecia- 
bly affected anylatse from leaf or meristem. High Mn managed to stimulate invertase in meristem, truc to hypothesis, but not nearly so well as did the inhibitor $\mathrm{Hg}$. In fact, the very appearance of a nutrient-solution additive usually served to activate invertase. However, such results need be deened negative only to the extent that we do not know how to interpret them.

\begin{tabular}{|c|c|c|c|c|c|c|c|}
\hline \multirow{2}{*}{ Item Xo. } & \multirow{2}{*}{ Enzy'me } & \multirow{2}{*}{ Trealment } & \multicolumn{4}{|c|}{$\begin{array}{l}\text { Results on diys following trentment } \\
\text { indicited }\end{array}$} & \multirow{2}{*}{ Me:s } \\
\hline & & & 0 & 3 & 9 & 27 & \\
\hline 1 & ATP-ase & Gontrol & 28.9 & 20.7 & 28.4 & 30.1 & 29.3 \\
\hline 2 & & Mn 50 & 27.4 & 41.4 & 24.9 & 24.4 & 29.5 \\
\hline 3 & & Mn 1,000 & 25,4 & 32.6 & 27.8 & 24.2 & 27.5 \\
\hline 4 & : & $\mathrm{Hg} 50$ & 27.3 & 32.4 & 26.2 & 23.5 & 27.4 \\
\hline 5 & ! & Elg 1,000 & 23.9 & 28.4 & 28.9 & 33.8 & 28.8 \\
\hline ii & G-1-P ;ise & Control & 6.5 & 6.0 & 6.7 & 6.3 & 0.4 \\
\hline 7 & & $M n 50$ & 5.0 & 6.1 & 5.2 & 5.2 & 5.4 \\
\hline 8 & & $\operatorname{M}[n 1,000$ & 4.7 & 5.1 & 5.3 & 4.3 & 4.8 \\
\hline 9 & · & $\mathrm{Hg} 50$ & 4.5 & 5.5 & 4.5 & 4.5 & 4.7 \\
\hline 10 & & $\mathrm{H}_{\mathrm{g}} 1,000$ & 4.8 & (i. 1 & 6.3 & 5.6 & 5.7 \\
\hline 11 & Amylaso & Control & 95.1 & 103.3 & 146.7 & 189.0 & 133.5 \\
\hline 12 & & $\operatorname{Mn} 50$ & 80.6 & 131.0 & 112.3 & 150.6 & 120.1 \\
\hline 13 & & $\operatorname{Min} 1,000$ & 81.1 & 116.2 & 157.6 & 137.3 & 123.1 \\
\hline 1.t & & $\mathrm{Hg} 50$ & 88.7 & 81.5 & 94.9 & 134.6 & 99.9 \\
\hline 15 & & IIg 1,000 & 85.7 & 35.7 & 32.9 & 141.3 & 73.9 \\
\hline
\end{tabular}

1 Each figure represents the computed mean of 3 replicates.

2 The numerals 50 and 1,000 signify coneentrations of 50 p.p.m. and 1,000 p.p.m., respectively.

\section{Protein analyses, experiments 1 and 2}

Reasons for the failure of $\mathrm{Mn}$ and $\mathrm{Hg}$ to yield predicuble effects upon invertase and anylase cannot be confirmed on the basis of cell-free experiments. True, high $\mathrm{Hg}$ did suppress anyluse in leaves, but only in concentrations so high as to threaten the life of the plant, and thus did not really support in vitro studies which suggested almost complete inbibition by mere traces of additive. Again, the expected comment here is that these in vivo experiments are only preliminary, that more $\mathrm{Hg}$ and $\mathrm{Mn}$ sources must bo tried, at different concentrations and with more mature plants. This is not so. If in vitro results were at all applieable to living tissues, umple opportunity was given for verification. 
Unexpected in vivo effects of enzyne regulators have been encountered earlier with immature cane $(\gamma, 6)$. It was suggested that both the synthosis of new enzyme protein and the in vivo letention of biochemical enzyme sequences, in contrast to isolation imposed by the test tube, accounted for discrepancies between test-tube based hypotheses and in vivo findings. Gross protein datu from the present studies strengthens our belief that treatment additives had influenced the production of enzyme protein.

It will be recalled that the only trentment of eonsequence during experi-

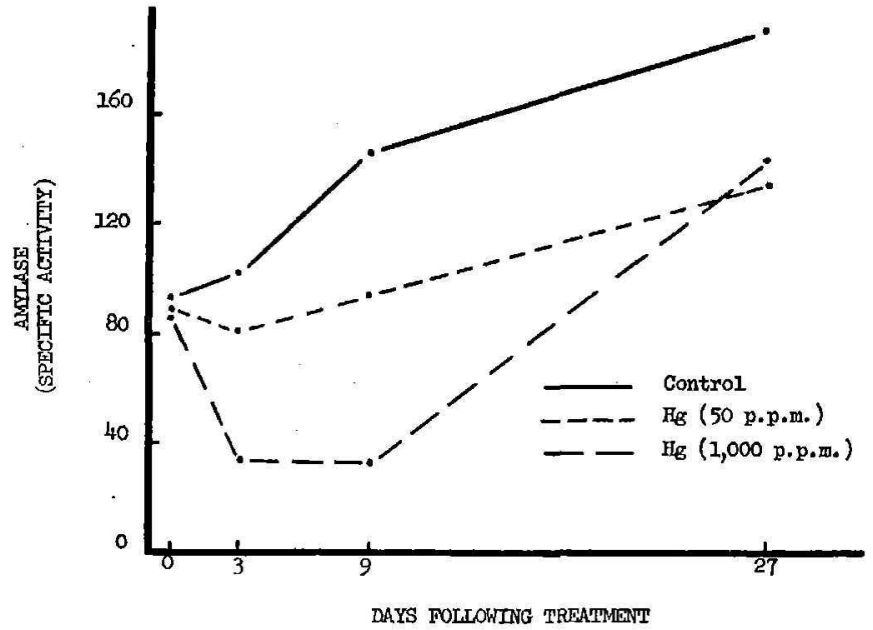

Fur. 3.- Inhibition of amylase from leaves of imunture sugareane following foliar applicution of mercury.

ment I was the foliar application of high $\mathrm{Hg}$, with subscquent deterioration of sucrose content and severe inhibition of amylase. This trentment likewise induced a relatively large increase of protein (table 8 , item 5 ). In meristem, where less drastic sugar and enzyme changes had been recorded, there were a general increase of prolein among all plants receiving foliar additives (taivle 8, items $7-10$ ). ${ }^{6}$

With the one exception of high Mn, plants receiving additives as nutrient-solution supplements also revealed a general incrense of meristem

- The protein increases ranged from 18 to 43 percent and were not in themselves large. However, it should be remembered that these are gross protein figures, including all enzyme protein as well as that which is noneatalytic. Within these ranges the content of any single enzyme could vary manyfold. 
protein (table 9). The contention that additives might stimulate protein synthesis is well enough vindicated. Supposedly, the initial appentance of an euzyne inhibitor can stimulate a recuperative mechanism which more than compensates for enzyme inuctivated. Yet, for all wo know of cane enzynes, which is not much, the materials supplied as "inhibitors" might ac-

TaBbe 5.-Menn specific-activity values for meristem cnzymes of immature sujarcane following foliar application of manganese and mereury ${ }^{1}$

\begin{tabular}{|c|c|c|c|c|c|c|c|}
\hline \multirow{2}{*}{ Itent No. } & \multirow{2}{*}{ Linzyme } & \multirow{2}{*}{ Treatment? } & \multicolumn{4}{|c|}{$\begin{array}{c}\text { Results on diys following treatment } \\
\text { intlicated }\end{array}$} & \multirow{2}{*}{ Mean } \\
\hline & & & 0 & 3 & b) & 27 & \\
\hline 1 & $\Lambda T P$-ise & Control & 25.1 & 34.7 & 25.9 & 23.0 & 27.2 \\
\hline 2 & & $M \| 50$ & 27.3 & 45.5 & 20.7 & 20.0 & 30.9 \\
\hline ; & & $\mathrm{Mn} 1,000$ & 24.1 & 31.1 & 21.2 & 22.9 & 24.8 \\
\hline 4 & & $\mathrm{Hr} 50$ & 23.7 & 34.2 & 17.4 & 23.1 & 24.6 \\
\hline 5 & & $\mathrm{H}_{\mathrm{ig}} 1,000$ & 38.0 & 29.8 & 22.5 & 32.3 & 30.7 \\
\hline bi & G-1-J' ase & Conf:mol & 8.5 & 0.7 & 7.7 & 7.4 & 7.6 \\
\hline 7 & & Mn 50 & 6.7 & 5.5 & 4.6 & 8.2 & 6.3 \\
\hline 8 & & $\operatorname{Mn} 1,000$ & 4.8 & 4.3 & 1.8 & 5.6 & 4.9 \\
\hline 9 & & $\mathbf{H}_{\kappa} 50$ & 6.1 & 3.6 & 3.9 & 6.0 & 4.9 \\
\hline 10 & & IIg 1,000 & 15.8 & 6.9 & ธ. 9 & บ. 0 & 0.4 \\
\hline 11 & Amylase & Cantrol & 56.5 & 80.5 & 65.0 & 63.0 & 68.5 \\
\hline 12 & & Mn 50 & 58.8 & 111.2 & 48.2 & 77.4 & 73.9 \\
\hline 13 & & Mn 1,000 & 51.5 & 85.3 & 51.9 & 67.6 & 61.1 \\
\hline 14 & & $\mathrm{Hg} 50$ & 54.3 & 84.6 & 42.0 & 67.9 & 62.4 \\
\hline 15 & & $\mathrm{Hg} 1,000$ & 56.1 & 75.9 & 71.4 & 76.0 & 69.9 \\
\hline 16 & Invertase & Contrnl & 20.1 & 11.9 & 27.2 & 8.5 & 16.7 \\
\hline 17 & & $\operatorname{Mn} 50$ & 24.2 & 13.8 & 14.5 & 12.7 & 16.3 \\
\hline 18 & & Mn 1,000 & 17.0 & 12.0 & 15.9 & 8.9 & 13.5 \\
\hline 19 & & $\mathrm{Hg} 50$ & 10.7 & 11.1 & 13.9 & 9.6 & 13.6 \\
\hline 20 & & $\mathrm{Hg} 1,000$ & 23.7 & 8.6 & 17.7 & 9.2 & 14.8 \\
\hline
\end{tabular}

I Each figure represents the computed mean of 3 replicates.

2 The numerals 50 and 1,000 signify concentrations of 50 p.p.m. and 1,000 p.p.n., respectively.

wally be true activators of a catalyst busy in the sequence of protein-forming reactions. A third consideration is the increased synthesis of endogenous enzyme inhibitors caused by treatments herein employed. Such inhibitors themselves need not be catalytic, nor even protein, yet as products of reactions independent from those of protein formation, they would help account for the in vivo vs. in vilro discrepancies recorded here.

Signs of a nonprotein entity are evident in the data already gachered. 


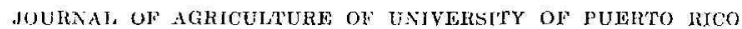

'l'sвце 6.-Sagar contenl of immatare sugarcane supplieth with variable iodide, tungston, mangancse, arsenate, and mercury in sand culurer ${ }^{1}$

\begin{tabular}{|c|c|c|c|c|c|c|c|}
\hline \multirow{2}{*}{ Item No. } & \multirow[b]{2}{*}{ Trealment" } & \multicolumn{3}{|c|}{ Leaí sugurs } & \multicolumn{3}{|c|}{ Meristem sugars } \\
\hline & & $\underset{\substack{\text { Total } \\
\text { ketose }}}{\text {. }}$ & Sucrose & Fructose & 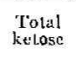 & Suerose & Fructose \\
\hline 1 & Gonfrol & 10.4 .6 & 83.0 & 20.7 & 299.9 & 111.4 & 188.5 \\
\hline 2 & $\mathrm{Mn}_{1}$ & 101.3 & 82.5 & 18.8 & 273.0 & $7 \notin .1$ & 198.8 \\
\hline 3 & $\mathrm{Mn}_{2}$ & 111.0 & 85.9 & 28.1 & 312.9 & 120.9 & 191.9 \\
\hline 1 & $\mathrm{H}_{\mathrm{H}_{1}}$ & 100.3 & $\pi 1.1$ & 20.2 & 233.8 & 53.3 & 180.5 \\
\hline 5 & $11 \mathrm{~g}:$ & 99.3 & 77.5 & 21.7 & 240.9 & 61.1 & 179.8 \\
\hline i & $l_{1}$ & 98.6 & 80.8 & 17.8 & 312.8 & 123.5 & 189.3 \\
\hline$i$ & 1. & 105.7 & 78.1 & 27.6 & 279.9 & 88.4 & 191.5 \\
\hline 8 & $w_{1}$ & 104.1 & 82.8 & 21.3 & 272.6 & 130.0 & 112.6 \\
\hline 9 & $W_{2}$ & 111.3 & 86.3 & 25.0 & 263.5 & 94.0 & 169.4 \\
\hline 10 & $\lambda s_{1}$ & 97.8 & 78.6 & 20.4 & 193.3 & 45.2 & 137.8 \\
\hline 11 & $A s_{2}$ & 102.1 & 7.1 .5 & 28.8 & 201.5 & 62.8 & 138.7 \\
\hline
\end{tabular}

${ }^{1}$ Each figure represents the emmputed mean of 3 replicates. Sugars ate expressed as milligrans per gram of dry weight.

${ }^{2}$ The numerals 1 and 2 refer to low and high additive levels. In exch instance this is 0.05 and 1.0 p.p.m.. respertively, with the exeeption of manganese, which was supplied at 2.5 and 25.0 p.p.m.

Tanus 7.-Mean specific-activily values for leuf and meristem cnzymes of immature sugarcane supplied wilh variable iodide, tungsten, mangancse, orsenate, and mereury in sand eallure

\begin{tabular}{|c|c|c|c|c|c|c|c|c|}
\hline \multirow{2}{*}{ Item No. } & \multirow{2}{*}{ Treatment? } & \multicolumn{3}{|c|}{ Leal enzymes } & \multicolumn{4}{|c|}{ Meristem enzymes } \\
\hline & & ATP-ase & G-1-1-asc & Amylase & ATP-ase & G-1-Pase & Amylase & Invcrlase \\
\hline 1 & Control & +7.9 & 11.6 & $20 \pi .7$ & 27.6 & 6.8 & 135.9 & 12.3 \\
\hline 2 & $W_{1}$ & $5+.9$ & 9.0 & 195.0 & 20.2 & 4.7 & 100.7 & $1+.2$ \\
\hline 3 & $M \cdot n n$ & 38.3 & 8.9 & 218.0 & 24.8 & 0.4 & 154.0 & 17.5 \\
\hline 1 & $\mathrm{Hg}_{k}$ & 45.9 & 6.6 & 204.9 & 24.1 & 7.7 & 119.6 & 28.8 \\
\hline 5 & $\mathrm{Hg}_{\underline{g}}$ & 52.3 & 8.4 & 254.9 & 22.2 & 8.0 & 116.4 & 23.2 \\
\hline i & $I_{2}$ & 19.3 & 11.5 & 222.8 & 25.7 & 7.0 & 132.9 & 15.0 \\
\hline 7 & $l_{2}$ & 51.0 & 8.6 & 199.4 & 20.7 & 5.6 & 100.2 & 17.2 \\
\hline 8 & $\mathbf{W}_{1}$ & 54.3 & 9.0 & 232.1 & 21.6 & 5.6 & 96.4 & 16.5 \\
\hline 0 & $W_{2}$ & 47.6 & 9.6 & 145.7 & 18.2 & 4.9 & 93.8 & 12.9 \\
\hline 10 & $A s_{1}$ & 57.5 & 7.9 & 243.1 & 21.9 & 7.1 & 111.5 & 25.0 \\
\hline 11 & A8? & 48.1 & 7.1 & 213.2 & 25.4 & 7.9 & 137.6 & 23.7 \\
\hline
\end{tabular}

1 Each figure represents the computed mean of 3 replicates.

2The numerals 1 and 2 refer to low and high additive levels. In each instance, this is 0.05 and 1.0 p.p.m., respectively, with the exception of manganese, which was supplied at 2.5 and 25.0 p.p.m. 
TAнLe 8,- Leaf and meristem prolein content of immatuse sugarcane following foliar applicalion of manganese and mercury ${ }^{1}$

\begin{tabular}{|c|c|c|c|c|c|c|c|}
\hline \multirow{2}{*}{ Item No. } & \multirow{2}{*}{ Data classification-- } & \multirow{2}{*}{ Treatment? } & \multicolumn{4}{|c|}{$\begin{array}{l}\text { Results on days following treatment } \\
\text { indicated }\end{array}$} & \multirow{2}{*}{ Meiu } \\
\hline & & & 0 & 3 & 9 & 27 & \\
\hline I & \multirow[t]{5}{*}{ Ienf protein } & Control & 5.78 & 5.66 & 5.09 & 5.43 & 5.49 \\
\hline 2 & & $\mathrm{Mn}_{10}$ & c. -10 & 4.60 & 5.95 & 6.07 & 5.77 \\
\hline 3 & & $\operatorname{Mn} 1,000$ & (i. 50 & 5.00 & 4.99 & 6.81 & 5.84 \\
\hline 1 & & Hg 50 & 5.99 & 5.38 & 5.99 & 6.35 & 5.93 \\
\hline 5 & & $\mathrm{Hy} 1,000$ & 6.49 & 6.93 & (i. 74 & 7.43 & 6.89 \\
\hline 6 & \multirow[t]{5}{*}{ Meristem protein } & Control & 18.64 & 14.80 & 15.76 & 1.4 .02 & 16.03 \\
\hline 7 & & $\operatorname{Mn} 50$ & 17.92 & 12,40 & 26.68 & 19.12 & 19.03 \\
\hline 8 & & Mu 1,000 & 21.64 & 16.00 & 26.84 & 26.20 & 22.67 \\
\hline 9 & & $\mathrm{Hg} 50$ & 19.90 & 18.60 & 29.12 & 24.12 & 22,95 \\
\hline 10 & & $\mathrm{Hg} 1,000$ & 20.40 & 22.40 & 16.60 & 19.40 & 19.70 \\
\hline
\end{tabular}

I Each figure represents the compuled mean of 3 replicates. Protein is expressed as milligrams per gram of dry weight.

2 The numerals 50 and 1,000 signily coneentrutions of 50 p.p.m. and 1,000 p.p.m., respectively.

Taвr.: 9.-Leaf and meristem prolein contcnt of immature sugarcane supplied with variable iodicle, lungsten, mangancse, arsenale, and mercury in sand culture

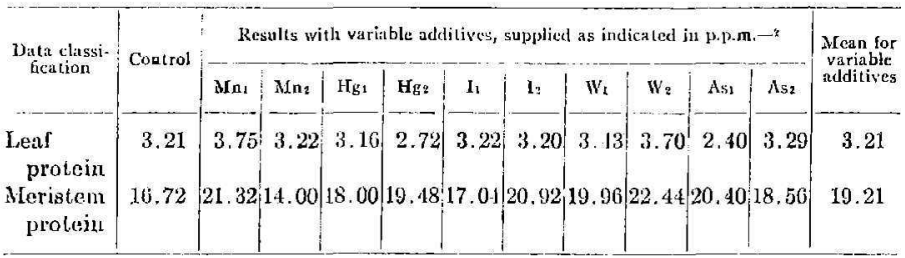

1 Lach figure representy the computed unean of 3 replicates. Protein is expressed as milligrams per gram of dry weight.

${ }^{2}$ The numerals 1 and 2 refer to low- and high-additive levels. In each instance this is 0.03 and 1.0 p.p.m., respectively, with the excoption of manganese, which was supplied at 2.5 and 25.0 p.p.m.

I'or example, the high $\mathrm{Hg}$ treatment which retarded leaf sucrose and anylase in experiment 1 caused a major protein increase some time after the 9-day harvest, whereas both the sucrose and anylase effects were well established at 3 days. Anylase activity was again on the rise when the major protein incroase was recorded at 27 days (fig. 3). This suggests that 
increased protein formation here was a corrective measure, a consequence of the severe $\mathrm{Hg}$ effect rather than a means of its execulion. Again, an investigator might have concluded that the stinulation of invertase during experiment 2 by $\mathrm{As}$ and $\mathrm{Hg}$ (table 7, items 4 and 5,10 and 11) was related to increased protein as a response to these same additives (table 9). Yet invertase activity was relatively low among plants receiving high $\mathrm{W}$ and low Mn (table 7, items 9 and 2), and these treatments induced the highest protein increases of that experiment (table 9).

Gross protein measuremenls camot distinguish for us the comparative effects of $\mathrm{Hg}, \mathrm{As}, \mathrm{W}$, and $\mathrm{Mu}$ upon individual conuponents of the increased protein, and this is the key for advancing such work in the future. Within a group of newly formed proteins; any of these treatments might have caused an increase of invertase, and any other treatment an incvease of invertase inhibitor. The next logical step will be the study of enzyme protein formation under controlled conditions, where the individual effects of additives upon the synthesis of general protein and specific catalysts can be measured.

\section{SUMMARY}

Immature sugarcane grown in sand culture was treated with manganese, an in ribro activitor of amylase and invertase, and with mercury, an in vitro inhibitor of the same cnzymes. Both elements were stuplied as foliar sprays and as nulrient-solution supplements. The objective was to determine whether in vivo effects would be equivalent to those observed in the test tube, and to determine the effects of these elements on sugar content. Leal and meristem tissues werc frozen and lyophilized for sugar and enzyme assay.

Mercury solution of 1,000-p.p.m. concentration (suused a marked suppression of leal amylase activity and sucrose content which persisted 27 days alter trentment. The major mencury effect was confined to the leaver. In meristen tissues, sucrose changes as established by control plants were conhanced by mercury and alleviated by manganese. Mereury at 1,000 p.p.m. caused a moderate invertase suppression which disappeared by 27 days after trealment.

Plants receiving mereury and manganese as nutrient-solution supplements experienced major sugar changes in muristem rather than leaves. Low manganese, and both high and low merrury, greatly suppressed sucrose coutent. Arsenate, which was also being tested, likewise rutsed marked deterioration of meristem sucrose. Invertase was generally stimulated anong plants receiving additives through their roots. Amylase was not affected. Mercury, an extremely efficient invertase inhibior in the test, tube, more than doubled invertase activity in plants receiving 0.05 p.p..m. of nescury in their nutrient solutions. 
In vino effects of manganese and mereury did not agree well with expectaltions based on in vitro observations. Even in those instances where thes anticipated results were gained, these required fiu greater consontrations of additive than should have been necessury. Nevertheless, definile influences were excrted mpon both amylase and invertase.

1)iserepancies between in vino and in vilpo desults are discussed. It is suggested that these differcuces are attributuble in the positioning of in vivo catalysts in reaction sequences, to the stimulation of prolein produetion by freatment atditives, and to the increased production of nomprotein, endogenous enzyme activalous and inhibitors.

\section{RESLMLN}

Se trató añi immadura sembrada en arena, con manganeso (agronte artivante de la amilasil y la invertatsa in vilo) y con nereurio (agente inhibidor de las misnus enzimas in vitro). Ambos elemenlos se ajpliram en forma de aspersión foliar y do solución nutritiva suplenentatiat. El propósito fue deferminar si los ofectos in viwo seŕan los mismos que se obtuvieron en el laboratorio, y determinar lambién ol ofecto de oston clementos sobre el contenirlo de aráne. Se congelanon y liofilizaron tejiclos foliares y del neristemo para al análisis del azúcur y las cuzimas.

Unil solución de meremio a unil roncentración de 1,000 p.p.m. melejo maradamento la actividad de la amilasa y do la sncurosa en la hoja, lo eual persistió hasta 27 días después del tratanicnto. El efecto principal del metruno se limitó a ha bojas. En los tejidos del meristemo, el meremio acoleró y el nanganeso redujo el patrón de cambios en la sacarosa, según lo establerieron las plantis-testigo. Bl nuerouio, a razón de 1,000 p.p.m., redujo moderadamente la acción de la invertasa, ofecto rue desapareció 27 días después del tratamiento.

Las plaulas que recibicton mereurio y manganeso en forma de solución

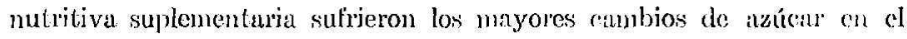
meristemo mas bien que en las hojas. In bajo nivel de manganeso y niveles altos y bajos de meremio, limitaron considerablemente el contenicto de sacarosa. El axseniato, que también se puso a prueba, fausi igualmonte un marcado deterioro de la sacurosa en el meristeno. En general, se estimuló la invertasa en aquellas plantas que recibieron aditivos per las raíces, sin que la amilasn se afectara. Is mercurio, que es un inhibidor de la inverlasa extruordinariamente eficaz en el laboratorio, auncutó más de dos veces la actividad de la invertasia en las plantats tratadiss ron unas solueiones nutritivas conteniendo 0.05 p.p.m de merrurio.

Los efectos del masiganeso y el mercurio in vimo no correspondieron a lo rue se esperaba, según las observaciones hechas in vitro. Aún en aquellits omasiones en que se obtuvieron los resultados que se esperahu, se 
requirieron concontraciones del aditivo en exceso a lo que debió ser necesario. No obstante, hubo influcncias definidas sobre la amilasa y la invertase.

Se discuten las discrepancias entre los resultados obtenidos in vitro é in vivo. Se sugiere Ia posibilidad de que estas diferencias se deban a la posicion de agentes catalíticos in vivo en secuencias reactivas, a la producción de proteína por el estímulo de los aditivos que se aplicaron; y al aumento en la producción de materias no-proteicas, activadores enzimúticos endógenos y agentes inhibidores.

\section{CITERATURE CITED}

1. Aloxauder, A. G., Sucrose-enzyme relationships in immature sugarcane as affected by varying levels of nitrate and potassium supplied in sand culture, J. Agr. Univ. P.R. 48(3): $165231,1064$.

2. - Changes in leaf sugar content and enzyme activity of immature sugarcane following foliar application of indole-3-acetic acid, 2,4-dichlorphenoxyacetic acid and tnaleic hydrazide, $\%$. $1 g r$. Univ. P.R. $49(1)$ : 1-34, 1965.

3. - Behavior of enzymes governing stareh- and sucrose-forming pathways in two sugarcane varioties supplied with variable nitrate and phosphate in sand culturc, J. Agr. Univ. P.R. 49(2): 153-74, 1965.

4. - - Fydrolytic proteins of sugaroune: The Acid Invertases, J. Agr. Univ. P.R. 49(3): $287-307,1965$.

5. - - Hydrolytic proteins of sugarcane: Amylase, $J$. Aqr. Univ. P.R. $49(3)$ : $308-24,1965$.

6. - Suerose-enzyme relationships in immature sugareane treated with variable molybdentun, calciun, iron, boron, lead, trichloroacetic acid, $\beta$-glyecrophosphute, and stareh, J. Agr. Univ. P.R. 49(4): 443-61, 1965.

7. - liffects of tungsien and molybdenum on sucrose content and hydrolytic enzymes of immature sugarcane, $J$. $4 \mathrm{gr}$. Univ. P.R. $49(4): 429-42,1965$.

8. Cardini, C. E., Jeloir, L. F., and Chiriboga, J., The biosynthesis of sucrose, $J$. Biol. Chem. 214: 149-55, 1955.

9. Glisziou, K. T., Accumulation and transformation of sugars in sugareane stalks: Mechanism of inversion of sitcrose in the inner space, Nalure 103: 1100, 1962.

10. Hartt, C. L., Studies on the invertase of sugareane, Hawazian Plant. Rec. 38: $193-206,1934$.

11. - - Potassimn deficiency in sugarcane, Bot. Gaz, 88: 220-61, 1924.

12. - - Some effects of potassium upon the amounts of protein and amino forms of nilrugen, sugars, and enzyne activity of sugaroane, Plont Physiol. 9: 453-90, 1934.

13. Hulch, M. D., Sitcher, J. A., and CHasziou, K. T., Sugar aceumulation cyole in sugitean I, Studies on enzymes of the cycle, Plant Physiol. 38: 338-43, 1963.

14. Hutch, M. D., and GIasziou, K. T., Sugar accumulation cycle in sugarcane, IT, Xelationships of invertase activity to sugar content and growth rate in storage tissue of plants grown in controlled environments, Plant Plysiol. $88: 344-8$, 1963.

15. Nenberg, C., and Mandl, I., in Sumner, J. B., and Myrback, K., The Enzymes, chapter 14, Academic Press, Inc., New York, N.Y., pp. 527-550, 1950. 


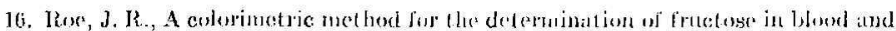

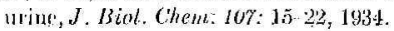

17. Sutherland, L. W., Cori, C. F., Haynes, R., and Olsen, N. S., Pluifical ion of the hypexglyeonic-glyeogenolytic factor from insulin and from gatkt lie muensa, J. Biol. Chem. 180: 825-37, 1942.

18. Sumner, J. B., and Somer's, G, F., Chomistry and Mothods of Enzymas, Leudenie l'ress, Inc, New York, N.Y., 1053. 